\title{
The Effect of Cold Stress on Damping-Off of Soybean Caused by Pythium sylvaticum
}

\author{
M. Serrano and A. E. Robertson, ${ }^{\dagger}$ Department of Plant Pathology and Microbiology, Iowa State University, Ames 50011
}

\begin{abstract}
To improve our understanding of the timing of cold stress and its effect on Pythium damping-off, we performed a factorial experiment with two cold stress temperatures $\left(4\right.$ and $\left.10^{\circ} \mathrm{C}\right)$; exposure to $96 \mathrm{~h}$ of cold stress at $0,1,2,4,6$, and 8 days after planting; and inoculation with Pythium sylvaticum-infested millet or control. Increased susceptibility to damping-off resulting in reduced emergence was found in inoculated plants when the cold stress period began 2 or 4 days after planting. In the noninoculated controls, no effect of cold stress on emergence was observed. Slower seedling growth was observed during the cold stress period and in inoculated plants after exposure to cold stress. Seed exudation, mycelial growth, and sporangia germination

of $P$. sylvaticum was evaluated at 4,10 , and $18^{\circ} \mathrm{C}$. The greatest seed exudation was observed at $4^{\circ} \mathrm{C}$. Low temperatures delayed mycelial growth of $P$. sylvaticum, although the pathogen was still able to grow at $4^{\circ} \mathrm{C}$. Sporangia incubated for $3 \mathrm{~h}$ at $18^{\circ} \mathrm{C}$ in the presence of seed exudates had higher germination in comparison with sporangia incubated at 10 or $4{ }^{\circ} \mathrm{C}$. Moreover, more sporangia germinated in response to seed exudates that were previously collected from seed imbibed for $24 \mathrm{~h}$ at low temperatures $\left(4^{\circ} \mathrm{C}\right)$. These results suggest that cold stress 2 to 4 days after planting increases soybean susceptibility to damping-off, presumably because of increased seed exudation and delayed seedling growth.
\end{abstract}

Soybean (Glycine max (L.) Merr.) is an important oilseed crop in Iowa and in the United States. In total, 83.4 million acres were planted in the United States in 2016. In Iowa, 9.5 million acres were planted to soybean in 2016 and the crop value was estimated at $\$ 5.4$ billion (USDA-NASS 2016).

Once a soybean field is planted, seedling disease may affect soybean production by reducing stands. Although reduced stands do not always result in yield loss, a farmer may need to replant the field. Later plantings may have reduced yield potential (De Bruin and Pedersen 2008). Seedling disease resulted in losses of up to 55 million bushels annually between 2010 and 2014, which was equivalent to $\$ 1.6$ billion for the 4-year period, and was ranked as the second to fourth most damaging disease of soybean in 12 states of northern the United States from 2010 to 2014 (Allen et al. 2017). Pythium spp. are the predominant pathogens causing seedling disease in Iowa and the north-central region of the United States (Murillo-Williams and Pedersen 2008; Rizvi and Yang 1996; Rojas et al. 2017). Pythium spp. are oomycetes that may prevent germination, causing a seed rot, or may also be associated with death of the developing seedling, which is known as "damping-off" (Hartman et al. 2015). Symptoms on affected seedlings may include general discoloration of the plant, yellow to brown lesions on the roots, root rot, and seed rot (Hartman et al. 2015), resulting in reduced stand and potential yield loss, which often require replanting of entire fields (Yang 1997, 1999).

Cool and wet soils are frequently associated with a higher occurrence of damping-off caused by Pythium spp., presumably because low temperatures at planting keep seedlings at a susceptible stage for a longer period of time, providing greater chances for seedling infection (Martin and Loper 1999). Moreover, field observations have suggested a role of cold stress in increasing the occurrence of

${ }^{\dagger}$ Corresponding author: A. E. Robertson; E-mail: alisonr@iastate.edu

Funding: The Iowa Soybean Association and the North Central Soybean Research Program provided funding for this research.

*The $\boldsymbol{e}$-Xtra logo stands for "electronic extra" and indicates that one supplementary figure and one supplementary table are published online.

Accepted for publication 16 May 2018.

() 2018 The American Phytopathological Society seedling diseases and poor plant stand (Bradley 2008; Robertson and Munkvold 2012). In controlled environments, Thomson et al. (1971) demonstrated that periods of cold stress $\left(4^{\circ} \mathrm{C}\right)$ at planting increased soybean susceptibility to damping-off. Similarly, in preliminary research, we observed that cold $\left(4^{\circ} \mathrm{C}\right)$ stress that occurred 1 day after planting increased the susceptibility of soybean to Pythium sylvaticum and reduced emergence by up to $70 \%$ (Serrano and Robertson 2016).

Planting soybean is not recommended if soil temperatures are below $13^{\circ} \mathrm{C}$ (Pedersen et al. 2004). Consequently, in Iowa, soybean crops are usually planted in late April through May, when soil temperatures are $13^{\circ} \mathrm{C}$ and warming. However, it is not uncommon for cold fronts to pass through the state and for soil temperatures to drop below $10^{\circ} \mathrm{C}$ for a few days (Serrano et al. 2015). It is unknown how cold stress that occurs a few to several days after planting affects the susceptibility of soybean to damping-off.

Cold stress has a detrimental effect on soybean germination and growth. For example, $50 \%$ of soybean seed germinated after $24 \mathrm{~h}$ at $23^{\circ} \mathrm{C}$ whereas, at $10^{\circ} \mathrm{C}, 120 \mathrm{~h}$ were required for $50 \%$ of seed to germinate (Duke et al. 1977). Once seed has germinated, hypocotyl elongation is extremely slow at or below $10^{\circ} \mathrm{C}$ (Hatfield and Egli 1974). In addition, when seed is planted at temperatures below $15^{\circ} \mathrm{C}$, there is a high risk of chilling injury during imbibition, and there is more seed exudation than at higher temperatures (Bramlage et al. 1978; Leopold 1980). The diffusion of those seed exudates is increased in wet soils and, consequently, more sporangia are stimulated to germinate (Stanghellini and Hancock 1971a). Seed exudates contain several compounds, including sugars, amino acids, volatile compounds, secondary metabolites, and unsaturated fatty acids, that stimulated sporangia germination within a few hours (Nelson 1987; Nelson and Craft 1989). High seed exudation of soluble carbohydrates resulted in more damping-off of soybean caused by Pythium spp. (Keeling 1974). Therefore, it is possible that, when cold stress occurs, greater seed exudation increases Pythium sporangia germination and, consequently, risk of infection.

Sporangia play a crucial role in the survival of some Pythium spp. in the soil (Nelson 2004; Stanghellini and Hancock 1971b). In addition, sporangia serve as primary inoculum that germinate in response to seed and root exudates (Martin and Loper 1999; Nelson 2004; Stanghellini and Hancock 1971a).

P. sylvaticum, first described by Campbell and Hendrix (1967), was one of the most frequently isolated species recovered from diseased soybean seedlings in recent surveys in Iowa and the north-central 
region of the United States (Matthiesen et al. 2016; Rojas et al. 2017). P. sylvaticum produces intercalary or terminal globose sporangia (hyphal swellings) that germinate directly in response to seed exudates and volatile compounds (Campbell and Hendrix 1967; Nelson 1987; Van der Plaats-Niterink 1981).

$P$. sylvaticum may cause more disease at lower temperatures. Rojas et al. (2017) found greater seed rot at 13 than at $20^{\circ} \mathrm{C}$. Although mycelial growth is optimal at $25^{\circ} \mathrm{C}$, the pathogen can grow at temperatures below $5^{\circ} \mathrm{C}$ (Van der Plaats-Niterink 1981). An improved understanding of how low temperatures affect the soybean$P$. sylvaticum interaction may help to explain the higher occurrence of damping-off observed after periods of cold stress.

The objectives of this study were to (i) determine how cold stress imposed at different times after planting affects the susceptibility of soybean to damping-off, (ii) measure the effect of cold stress on mycelial growth and sporangia germination of $P$. sylvaticum, (iii) evaluate the effect of cold stress on soybean seed exudation during imbibition, and (iv) compare sporangia germination in response to seed exudates from seed imbibed at different temperatures. We hypothesized that, because $P$. sylvaticum is able to grow at low temperatures and soybean germination and growth is slowed during periods of cold stress, exudates released from the germinating seed stimulate sporangia germination that results in infection of the soybean

Table 1. Effect of different variables on probability of emergence of soybean (IA 2094) in the growth chamber

\begin{tabular}{lc}
\hline Effect & P value, probability of emergence \\
\hline Run & 0.4769 \\
Temperature & 0.0006 \\
Timing & $<0.0001$ \\
Pathogen & $<0.0001$ \\
Temperature $\times$ timing & 0.3128 \\
Temperature $\times$ pathogen & 0.0073 \\
Timing $\times$ pathogen & $<0.0001$ \\
Temperature $\times$ timing $\times$ pathogen & 0.0066 \\
\hline
\end{tabular}

seedling and, consequently, increased damping-off. The data from this study will improve our understanding of how periods of cold stress that occur soon after planting increase the occurrence of damping-off and this, in turn, will help to improve disease management recommendations.

\section{Materials and Methods}

Plant material and $\boldsymbol{P}$. sylvaticum culture. All experiments were done using soybean cultivar IA 2094, which has a relative maturity of 2.4 and was susceptible to Pythium damping-off in previous experiments (Serrano and Robertson 2016; Weidenbenner et al. 2014). $P$. sylvaticum isolate IASO 2-8.18 (Matthiesen et al. 2016) was used for inoculum production, mycelial growth, and sporangia germination experiments. P. sylvaticum was grown on $4 \%$ V8 juice media plus neomycin sulfate $(0.05 \mathrm{~g} /$ liter $)$ and chloramphenicol $(0.01$ $\mathrm{g} /$ liter) $\left(\mathrm{dV}^{++}\right)$(Matthiesen et al. 2016).

Cold stress growth chamber assay. $P$. sylvaticum-infested millet was used as a source of inoculum. Autoclavable bags with a filter patch (Myco Supply Company Inc., Pittsburgh) were filled with approximately $600 \mathrm{ml}$ of millet seed that had been soaked overnight and autoclaved twice, with $24 \mathrm{~h}$ between each cycle. $P$. sylvaticum was grown on $\mathrm{dV}^{++}$(Matthiesen et al. 2016) in the dark at room temperature $\left(20^{\circ} \mathrm{C}\right)$. Each bag was inoculated with 20 pieces $\left(1 \mathrm{~cm}^{2}\right)$ of media colonized with 3 -day-old mycelium of $P$. sylvaticum. The inoculated bags were kept in the dark at room temperature $\left(20^{\circ} \mathrm{C}\right)$ for 10 days. The bags were gently shaken once per day to ensure colonization of all millet seed.

Vermiculite ( $90 \mathrm{ml} / \mathrm{cup})$ was added to polystyrene cups $(237 \mathrm{ml})$ with three 2-mm-diameter holes punched through the base of the cup. A layer of pathogen-infested or sterile millet ( $5 \mathrm{ml} / \mathrm{cup}$ ) was placed on top of the vermiculite and a second layer of $40 \mathrm{ml}$ of vermiculite covered the millet. Ten soybean seeds per cup were placed on the second layer of vermiculite, before a final layer of vermiculite $(90 \mathrm{ml})$ was used to cover the seed. The cups were placed in a growth chamber at $18^{\circ} \mathrm{C}$ and periods of $12 \mathrm{~h}$ of light and $12 \mathrm{~h}$ of darkness. The cups were watered with tap water until runoff at planting and then watered with $50 \mathrm{ml}$ of tap water every other day.

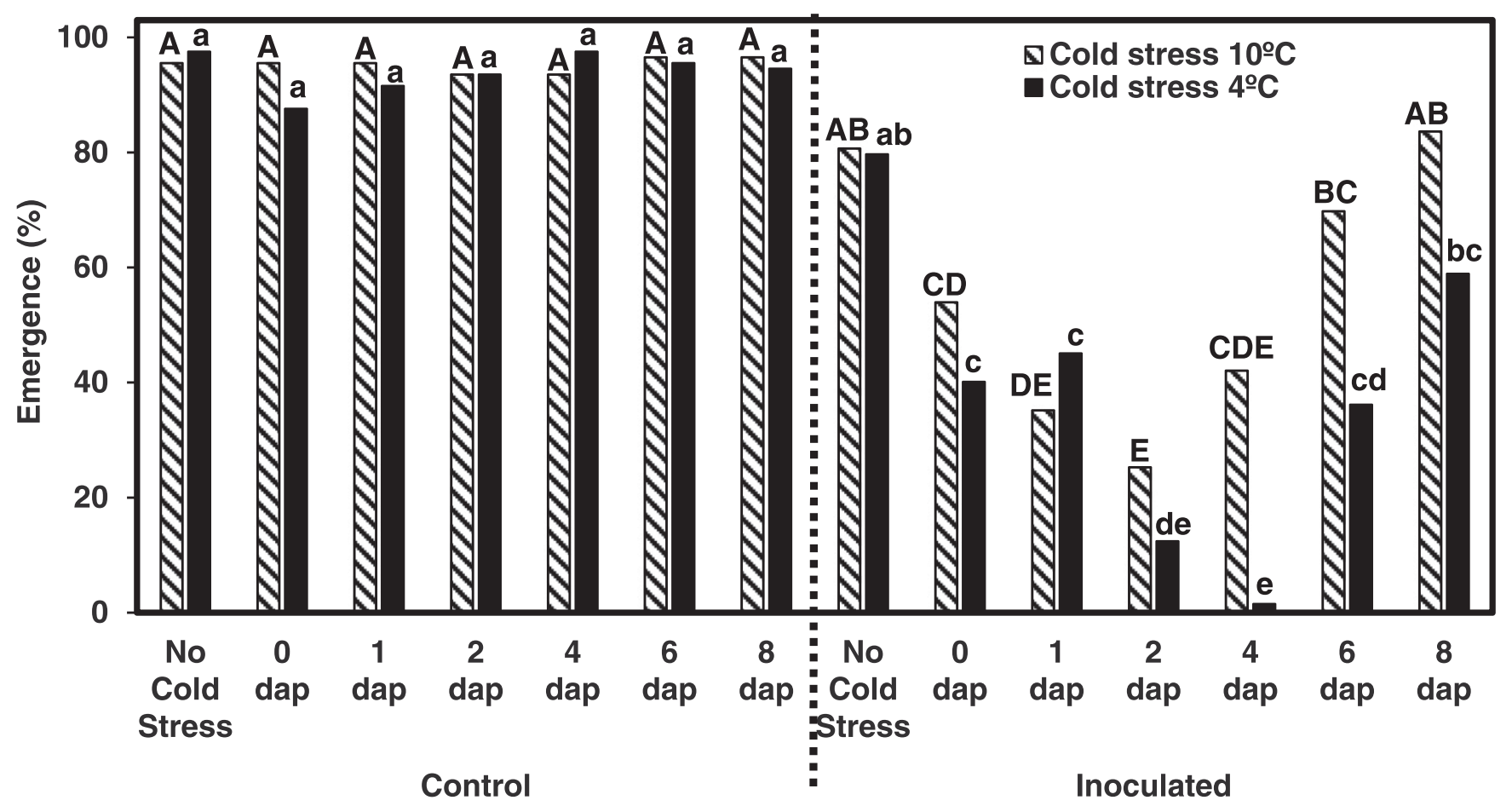

Cold stress timing

Fig. 1. Emergence (\%) of soybean IA 2094 noninoculated (control) and inoculated with Pythium sylvaticum subjected to $96 \mathrm{~h}$ of cold stress $\left(4\right.$ or $10^{\circ} \mathrm{C}$ ) at different days after planting (dap). Different letters indicate significant differences according to Tukey's test $(\alpha=0.05)$; uppercase letters for cold stress at $10^{\circ} \mathrm{C}$ and lowercase letters for cold stress at $4^{\circ} \mathrm{C}$ 
The experimental design was a three-way (two by seven by two) factorial of cold stress temperature, timing of cold stress, and inoculation, respectively, with five replications. Two cold stress temperatures $\left(4\right.$ or $10^{\circ} \mathrm{C}$, for $96 \mathrm{~h}$ ) were used. Cold stress timing was imposed at $0,1,2,4,6$, and 8 days after planting (dap) and a no-cold-stress control. Cups were inoculated with $P$. sylvaticum-infested millet or sterile millet (noninoculated control). Final emergence data were taken 21 dap. Emergence was assessed 3, 6, 7, 8, 10, 13, 16, 18, and 21 dap by counting the number of seedlings with cotyledons completely emerged from the vermiculite.

Three additional replications of the above treatments were planted for use in measuring seedling length at each time. Seedling length was measured from the proximal end of the cotyledon to the root tip, as described by Ellis et al. (2011). Seedling growth was measured at the beginning and at the end of the $96-\mathrm{h}$ period at 4,10 , and $18^{\circ} \mathrm{C}$ for each treatment. Also, to determine whether cold stress reduced seedling growth once the plants were returned to optimal temperatures for growth, seedling growth was measured $72 \mathrm{~h}$ after returning the plants to $18^{\circ} \mathrm{C}$. All experiments were repeated once.

Growth of $P$. sylvaticum at different temperatures. One plug ( $3 \mathrm{~mm}$ in diameter) of $P$. sylvaticum-colonized $\mathrm{dV}^{++}$media was placed $2 \mathrm{~mm}$ from the edge of a 90-mm-diameter petri dish plate filled with $20 \mathrm{ml}$ of $\mathrm{dV}^{++}$media, and incubated in the dark at 4 , 10 , or $18^{\circ} \mathrm{C}$. Mycelial growth from the edge of the plug to the furthest edge of the colony was measured 48, 72, and $96 \mathrm{~h}$ after inoculation.

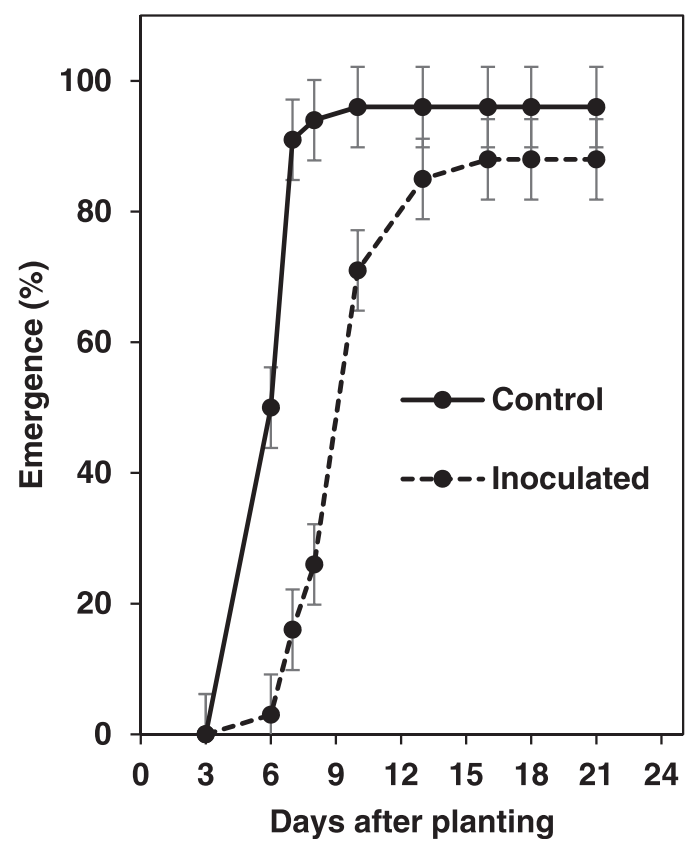

Fig. 2. Emergence (\%) of soybean IA 2094 noninoculated (control) and inoculated with Pythium sylvaticum at different days after planting at $18^{\circ} \mathrm{C}$. Error bars indicate confidence interval 95\%. Area under the curve was significantly different between the curves $(P<0.0001)$. The area under the curve was $1,484.0 \%$ days and 1,065.5\%-days for noninoculated and inoculated plants, respectively.
The experimental design was completely randomized with five replicates. The experiment was repeated once.

Solute leakage after imbibition of seed at different temperatures. To estimate the amount of seed exudates released from seed imbibed at different temperatures, solute leakage was measured with the Electrical Conductivity Test modified from AOSA (2009). Soybean seed were inspected visually for damage to the seed coat and undamaged seed were selected for the test. Four reps of 50 seeds per treatment were weighed and then imbibed for $24 \mathrm{~h}$ in $75 \mathrm{ml}$ of distilled sterile water at 4,10 , and $18^{\circ} \mathrm{C}$. The water was equilibrated for at least $4 \mathrm{~h}$ in growth chambers at each temperature before imbibition. After imbibition, the seed were removed and the remaining solution was equilibrated at $25^{\circ} \mathrm{C}$ for at least $4 \mathrm{~h}$. The electrical conductivity of each replication of each solution was measured with an Electrical Conductivity meter (Solution Analyzer, Model 4603; Amber Science Inc., San Diego, CA) that had been calibrated with a potassium chloride conductivity standard solution $(718 \mu \mathrm{S} / \mathrm{cm})$ at $25^{\circ} \mathrm{C}$ (Ricca Chemical Company, Arlington, TX). The conductivity of a water control (blank) was subtracted from each reading before calculations of electrical conductivity were done. Data for electrical conductivity were calculated per gram of seed weight for each replicate. The experiment was repeated once.

Production of sporangia for sporangia germination assays. P. sylvaticum was grown on $\mathrm{dV} 8^{++}$media at $24^{\circ} \mathrm{C}$ for $48 \mathrm{~h}$ in the dark. A method modified from Nelson and Craft (1989) was used for sporangia production. Briefly, colonized disks (3 $\mathrm{mm}$ in diameter) from 2day-old cultures of the pathogen were placed in sterile petri dishes and submerged for two consecutive 10-min periods in approximately $20 \mathrm{ml}$ of leaching buffer (pH 5.8) containing $0.01 \mathrm{M} \mathrm{Na}\left(\mathrm{NO}_{3}\right)_{2}$. $4 \mathrm{H}_{2} \mathrm{O}, 0.004 \mathrm{M} \mathrm{MgSO}_{4} \cdot 7 \mathrm{H}_{2} \mathrm{O}$, and $0.005 \mathrm{M} \mathrm{KNO}_{3}$, followed by one 3-h submergence period. The buffer was replaced with fresh buffer after each 10-min period of submergence. Finally, the disks were rinsed with sterile distilled water and incubated in a sterile petri dish at $24^{\circ} \mathrm{C}$ for $48 \mathrm{~h}$ to facilitate sporangia production.

Effect of exudates from seed imbibed at cold temperatures on sporangia germination. A modification of the method described by Nelson and Craft (1989) was used to assess percent germination of

Table 3. Mean growth of soybean seedlings IA 2094 that were noninoculated (control) or inoculated with Pythium sylvaticum and placed at 4,10 , or $18^{\circ} \mathrm{C}$ for $96 \mathrm{~h}$ at various days after planting (dap) ${ }^{\mathrm{z}}$

\begin{tabular}{|c|c|c|c|c|c|c|}
\hline \multirow{3}{*}{$\begin{array}{l}\text { Cold stress period } \\
\text { (dap) }\end{array}$} & \multicolumn{6}{|c|}{ Mean growth (mm) } \\
\hline & \multicolumn{3}{|c|}{ Control (noninoculated) } & \multicolumn{3}{|c|}{ P. sylvaticum-inoculatec } \\
\hline & $18^{\circ} \mathrm{C}$ & $10^{\circ} \mathrm{C}$ & $4^{\circ} \mathrm{C}$ & $18^{\circ} \mathrm{C}$ & $10^{\circ} \mathrm{C}$ & $4^{\circ} \mathrm{C}$ \\
\hline 0 & $48.6 \mathrm{c}$ & 1.7 & 0.1 & $28.1 \mathrm{~b}$ & 0.9 & 0.1 \\
\hline 1 & $68.5 \mathrm{~b}$ & 8.5 & 1.3 & $35.4 \mathrm{ab}$ & 7.1 & 1.0 \\
\hline 2 & $78.3 \mathrm{ab}$ & 9.0 & 2.7 & $35.6 \mathrm{ab}$ & 4.0 & 0.7 \\
\hline 4 & $91.5 \mathrm{a}$ & 8.2 & 1.6 & $40.2 \mathrm{ab}$ & 1.2 & 0.9 \\
\hline 6 & $82.6 \mathrm{ab}$ & 4.0 & 0.0 & $50.9 \mathrm{a}$ & 2.4 & 0.1 \\
\hline 8 & $50.7 \mathrm{c}$ & 5.8 & 2.9 & $42.8 \mathrm{ab}$ & 7.9 & 1.6 \\
\hline$P$ value & $<0.0001$ & 0.0533 & 0.2556 & 0.0475 & 0.0866 & 0.374 \\
\hline
\end{tabular}

${ }^{\mathrm{z}}$ Temperature of $18^{\circ} \mathrm{C}=$ no cold stress (control). Different letters in the same column indicate significant differences according to Tukey's test $(\alpha=0.05)$.

Table 2. Comparison of mean growth of soybean seedlings IA 2094 that were noninoculated (control) or inoculated with Pythium sylvaticum at 4,10 , or $18^{\circ} \mathrm{C}$ for $96 \mathrm{~h}^{\mathrm{z}}$

\begin{tabular}{lccc}
\hline Seedlings & Temperature $\left({ }^{\circ} \mathbf{C}\right)$ & Seedling growth $(\mathbf{m m})$ & Mean seedling growth $(\mathbf{m m})$ \\
\hline Control (noninoculated) & 18 & $70.0 \mathrm{a}$ & $25.9 \mathrm{a}$ \\
& 10 & $6.2 \mathrm{c}$ & $\ldots$ \\
$P$. sylvaticum-inoculated & 4 & $1.4 \mathrm{~d}$ & $\ldots$ \\
& 18 & $38.8 \mathrm{~b}$ & $\ldots$ \\
$P$ value & 10 & $3.9 \mathrm{~cd}$ & $\ldots$ \\
\hline
\end{tabular}

${ }^{\mathrm{z}}$ Different letters in the same column indicate significant differences according to Tukey's test $(\alpha=0.05)$. 
sporangia in response to seed exudates from seed imbibed at different temperatures. Prepared culture disks containing sporangia were placed approximately $10 \mathrm{~mm}$ apart on sterile glass slides (three culture disks per slide). Either seed exudate from seed imbibed at 4, 10, or $18^{\circ} \mathrm{C}$ (as described above) or sterile water $(10 \mu l$ each) was pipetted carefully on top of each culture disk so that the disk was submerged in the solution. The slides of each culture disk were incubated for 2 and $3 \mathrm{~h}$ at $24^{\circ} \mathrm{C}$ in the dark; then, the culture disks were stained with $0.03 \%$ acid fuchsin in $85 \%$ lactic acid and examined microscopically $(\times 200)$. The number of germinated and nongerminated sporangia within the whole culture disk was recorded. Each examined culture disk contained at least 30 sporangia, for a total of 270 to 540 sporangia counted by treatment. The experimental design was a randomized complete block with three imbibition-temperature treatments and three replicates. The replication unit was a slide with three culture disks. The experiment was repeated once.

Effect of cold temperatures on sporangia germination. To evaluate the effect of temperature on sporangia germination, soybean seed were imbibed at $18^{\circ} \mathrm{C}$, as described above, and $10 \mu l$ of the seed exudate solution or sterile water was pipetted on top of culture disks as described above. The slides were incubated for $3 \mathrm{~h}$ at either 4,10 , or $18^{\circ} \mathrm{C}$ in the dark. The culture disks were stained and sporangia were counted as described above. The experimental design was a randomized complete block with three incubation-temperature treatments and three replicates. The examined culture disks contained at least 30 sporangia for a total of 270 to 540 sporangia counted by treatment. The replication unit was a slide with three culture disks. The experiment was repeated once.

Data analysis. All data were analyzed using SAS 9.3 (SAS Institute, Cary, NC). Emergence 21 dap was analyzed with PROC LOGISTIC to model the probability of emergence as a function of treatments testing temperature, timing, and pathogen as fixed factors, with all the interactions. Area under the emergence curve was calculated as described by Campbell and Madden (1990) and analyzed with PROC GLIMMIX testing the effect of treatment as a fixed factor. Seedling growth was analyzed with PROC GLIMMIX testing treatment, timing, and its interaction as fixed factors. Mycelial growth was analyzed with PROC GLIMMIX testing temperature, time, and temperature-time as fixed factors, and the random effect run-temperature-replication was included to account for the correlation between measurements on the same plate across three units of time. Seed exudation (solute leakage) was analyzed with PROC GLIMMIX testing temperature as a fixed factor. Sporangia germination data were analyzed with PROC GLIMMIX testing treatment as a fixed factor and block as a random factor. When a treatment effect was detected $(P<0.05)$, Tukey's test $(\alpha=0.05)$ was used for mean comparisons.

\section{Results}

Effect of cold stress at different times after planting on soybean growth and susceptibility to $\boldsymbol{P}$. sylvaticum. Significant differences in emergence among treatments were detected for cold stress temperatures $(P=0.0006)$, cold stress timing $(P<0.0001)$, and presence of the pathogen $(P<0.0001)$. A temperature-pathogen interaction $(P=$ $0.0073)$ and timing-pathogen $(P<0.0001)$ interaction was detected (Table 1). Overall, inoculated cups exposed to $4^{\circ} \mathrm{C}$ at 2 and 4 dap showed a reduction of 88 to $99 \%$ in emergence, followed by cups exposed to $10^{\circ} \mathrm{C}$ at 2 and 4 days that showed a reduction in emergence between 58 to $75 \%$ (Fig. 1). The reduction in emergence 2 and 4 dap was not observed in noninoculated cups subjected to cold stress at either 4 or $10^{\circ} \mathrm{C}$. Furthermore, when cold stress was absent, no differences in emergence were observed between inoculated and noninoculated treatments (Fig. 1). However, when cold stress was absent, the area under emergence curve was reduced in inoculated cups in comparison with the noninoculated cups $(P<0.0001)$ (Fig. 2).

Seedlings inoculated with $P$. sylvaticum were shorter in comparison with noninoculated plants $(P<0.0001$; Table 2$)$. When the pathogen was absent, cold stress reduced seedling growth. Less seedling growth was observed at 4 and $10^{\circ} \mathrm{C}$ compared with $18^{\circ} \mathrm{C}(P<$ 0.0001; Table 2). In the inoculated cups at $18^{\circ} \mathrm{C}, P$. sylvaticum reduced seedling growth in comparison with the noninoculated control. However, the presence of the pathogen did not further reduce seedling growth in plants subjected to cold stress at 4 and $10^{\circ} \mathrm{C}(P>$ 0.05; Table 2).

When the time of initiation of cold stress (cold stress timing) was compared, differences in seedling growth were observed at $18^{\circ} \mathrm{C}$ in both noninoculated and inoculated plants $(P<0.0001$ and $P=$ 0.0475 , respectively; Table 3$)$. At $18^{\circ} \mathrm{C}$, the seedling growth was reduced the most by the 96-h cold stress period that started 0 dap in both inoculated and noninoculated plants. Seedling growth was also reduced by a cold stress period that started 8 dap only in the noninoculated plants. No effect of cold stress timing on seedling growth was observed at 4 and $10^{\circ} \mathrm{C}$ (Table 3 ).

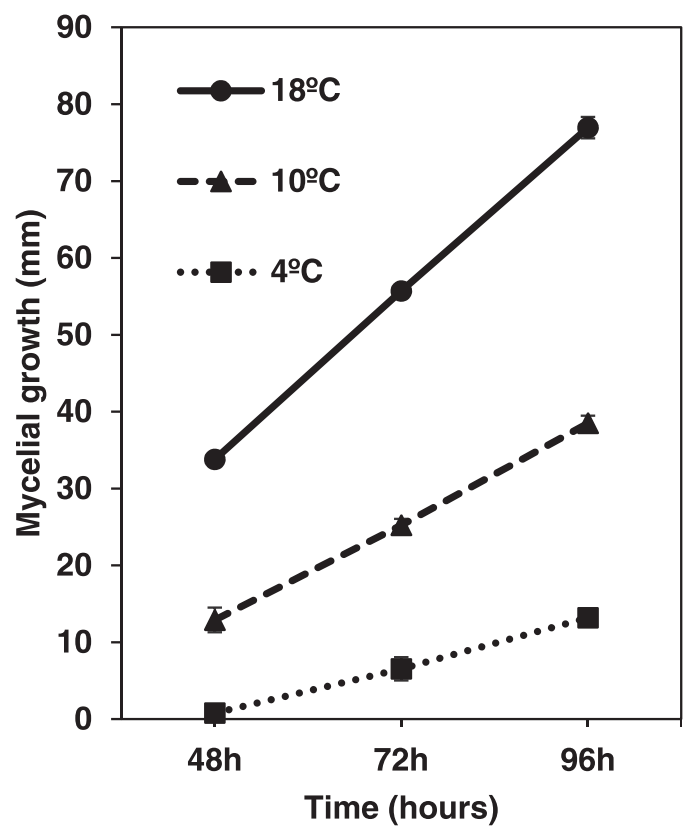

Fig. 3. Mycelial growth of Pythium sylvaticum at three temperatures on dilute V8 media plus antibiotics. Error bars indicate standard deviation.

Table 4. Comparison of the growth of soybean that were noninoculated (control) or inoculated with Pythium sylvaticum, subjected to a period of cold stress ( $96 \mathrm{~h}$ at 4 or $\left.10^{\circ} \mathrm{C}\right)$, or kept at an optimum growth temperature $\left(18^{\circ} \mathrm{C}\right)$ after a rewarming period $\left(72 \mathrm{~h} \mathrm{at} 18^{\circ} \mathrm{C}\right)^{\mathrm{z}}$

\begin{tabular}{lccc}
\hline Soybean & Previous temperature $\left({ }^{\circ} \mathbf{C}\right)$ & Seedling growth $(\mathbf{m m})$ & Mean seedling growth $(\mathbf{m m})$ \\
\hline Control (noninoculated) & 18 & $45.3 \mathrm{ab}$ & $45.4 \mathrm{a}$ \\
& 10 & $46.7 \mathrm{a}$ & $\ldots$ \\
P. sylvaticum-inoculated & 4 & $38.4 \mathrm{~b}$ & $\ldots$ \\
& 18 & $26.9 \mathrm{c}$ & $\ldots .3 \mathrm{~b}$ \\
$P$ value & 10 & $19.3 \mathrm{~d}$ & $\ldots$ \\
\hline
\end{tabular}

${ }^{\mathrm{z}}$ Different letters in the same column indicate significant differences according to Tukey's test $(\alpha=0.05)$. 
After the 96-h cold stress period at 4 or $10^{\circ} \mathrm{C}$, the seedling growth in a subsequent period of $72 \mathrm{~h}$ at $18^{\circ} \mathrm{C}$ (rewarming period) was compared with the growth of seedlings that had been continually at $18^{\circ} \mathrm{C}$. During the rewarming period, less seedling growth was observed in plants inoculated with $P$. sylvaticum in comparison with noninoculated plants $(P<0.0001$; Table 4$)$. Plants inoculated with $P$. sylvaticum and previously subjected to cold stress at 4 and $10^{\circ} \mathrm{C}$ were shorter in comparison with plants previously subjected to $18^{\circ} \mathrm{C}$ $(P<0.0282$; Table 4).

When the effect of cold stress timing on seedling growth was compared in the subsequent rewarming period $\left(18^{\circ} \mathrm{C}\right)$ of $72 \mathrm{~h}$, significant differences were observed in noninoculated plants at 18,10 , and $4^{\circ} \mathrm{C}$ $(P<0.0001, P<0.0001$, and $P=0.0023$, respectively) and in inoculated plants at 18 and $4^{\circ} \mathrm{C}(P=0.0015$ and $P=0.0098$, respectively). Less seedling growth occurred when the cold stress timing occurred 8 dap in both noninoculated and inoculated plants at $18^{\circ} \mathrm{C}$ (Supplementary Table S1).

Effect of temperature on the growth of $P$. sylvaticum. There were significant differences in mycelial growth of $P$. sylvaticum $(P<0.0001)$ at different temperatures. Growth was greater at 18 compared with $10^{\circ} \mathrm{C}$ and at 18 compared with $4{ }^{\circ} \mathrm{C}$ at each time point assessed (Fig. 3).

Effect of temperature on seed exudation during imbibition of soybean seed. Higher solute leakage (seed exudation) occurred when seed were imbibed at $4^{\circ} \mathrm{C}$ in comparison with 10 and $18^{\circ} \mathrm{C}(P<$ 0.0001; Table 5).

Effect of seed exudates from seed imbibed at cold temperatures on sporangia germination. $P$. sylvaticum sporangia germinated after exposure to seed exudate solutions but not when they were exposed to sterile water $(P<0.0001)$ (Table 6$)$. After $3 \mathrm{~h}$ of exposure to seed exudates from seed imbibed at $4^{\circ} \mathrm{C}$, more sporangia germinated compared with those exposed to a solution of seed exudates from seed imbibed at 10 and $18^{\circ} \mathrm{C}(P<0.0001)$.

Sporangia germination after incubation at 4,10 , or $18^{\circ} \mathrm{C}$. Differences in sporangia germination were detected between runs $(P=$ $0.0086)$ (Table 7). In both runs, however, greater sporangial germination occurred at 18 than at 10 or $4^{\circ} \mathrm{C}(P<0.0001)$. No sporangia germinated in sterile water.

\section{Discussion}

In this study, we demonstrated that periods of cold stress that occurred between 2 and 4 dap increased the susceptibility of soybean to

Table 5. Seed exudation (solute leakage) of soybean IA 2094 seed after incubation in distilled water for $24 \mathrm{~h}$ at different temperatures

\begin{tabular}{lc}
\hline Temperature $\left({ }^{\circ} \mathbf{C}\right)$ & Leakage $(\boldsymbol{\mu S} / \mathbf{c m ~} \mathbf{g})^{\mathbf{z}}$ \\
\hline 4 & $65.9 \mathrm{a}$ \\
10 & $59.6 \mathrm{~b}$ \\
18 & $56.9 \mathrm{~b}$ \\
$P$ value & $<0.0001$ \\
\hline
\end{tabular}

${ }^{\mathrm{z}}$ Different letters indicate significant differences according to Tukey's test $(\alpha=0.05)$.

Table 6. Sporangia germination of Pythium sylvaticum after exposure to seed exudates from seed imbibed at different temperatures and incubation at $24^{\circ} \mathrm{C}$ for 2 and $3 \mathrm{~h}$

\begin{tabular}{lcc}
\hline & \multicolumn{2}{c}{$\begin{array}{c}\text { Germinated sporangia }(\boldsymbol{\%}) \\
\text { at } \mathbf{2 4}^{\circ} \mathbf{C}^{\mathbf{y}}\end{array}$} \\
\cline { 2 - 3 } Seed exudate & $\mathbf{2} \mathbf{~ h}$ & $\mathbf{3 ~ h}$ \\
\hline Seed imbibed at $4^{\circ} \mathrm{C}$ & $35.5 \mathrm{a}$ & $65.2 \mathrm{a}$ \\
Seed imbibed at $10^{\circ} \mathrm{C}$ & $32.0 \mathrm{a}$ & $42.9 \mathrm{~b}$ \\
Seed imbibed at $18^{\circ} \mathrm{C}$ & $31.9 \mathrm{a}$ & $48.2 \mathrm{~b}$ \\
Sterile water & $0.6 \mathrm{~b}$ & $0.5 \mathrm{c}$ \\
$P$ value & $<0.0001$ & $<0.0001$ \\
\hline
\end{tabular}

${ }^{\mathrm{y}}$ Different letters indicate significant differences according to Tukey's test $(\alpha=0.05)$.

${ }^{\mathrm{z}}$ Three seed exudates were prepared by imbibition of soybean seed in sterile water at 4,10 , or $18^{\circ} \mathrm{C}$ for $24 \mathrm{~h}$. damping-off under controlled conditions. To our knowledge, this study is the first to evaluate the effect of cold stress after planting on emergence. Previous studies evaluating the effect of suboptimal temperatures on germination of soybean have been done to study chilling injury during imbibition or when screening cold-tolerant varieties in field trials and laboratory experiments (Cabane et al. 1992; Hobbs and Obendorf 1972; Ismail et al. 1989; Littlejohns and Tanner 1976). The cold-stress treatments that we tested mimic what occurs in the field soon after planting in Iowa when cold fronts pass through the region for a few days, resulting in suboptimal soil temperatures for germination and seedling development. Previous research suggested that cold soils delay emergence and, thus, provide a greater chance for seedling infection (Martin and Loper 1999). In this study, we demonstrated that the timing at which cold temperatures are initiated can have substantial impact on the incidence of damping-off caused by $P$. sylvaticum.

Similarly, Thomson et al. (1971) reported that cold stress increased susceptibility to damping-off but, in their experiments, cold stress $\left(4^{\circ} \mathrm{C}\right)$ was applied only at planting. They also observed reduced emergence in their noninoculated control that may have been a consequence of chilling injury during imbibition, which is common at temperatures below $15^{\circ} \mathrm{C}$ (Bramlage et al. 1978; Leopold 1980). In our study, we did not observe reduced emergence when cold stress was applied at planting, possibly because it took 3 to $4 \mathrm{~h}$ to equilibrate the temperature inside the cup to the growth chamber temperature (Supplementary Fig. S1). Seed imbibition is the first event in the germination process and high water uptake occurs within the first 35 min of planting the seed. During this time, seed are particularly susceptible to imbibitional chilling injury because rearrangement of cell membranes occurs during the first few minutes of imbibition (Bramlage et al. 1978; Parrish and Leopold 1977; Vertucci and Leopold 1983). In the first $30 \mathrm{~min}$ after planting in our study, the temperature of our cups was $19^{\circ} \mathrm{C}$ and it took 3 to $4 \mathrm{~h}$ for our cups to reach $4^{\circ} \mathrm{C}$. Thus, the risk of imbibitional chilling injury in our experiments was likely low.

No significant reduction in emergence was observed in the coldstress treatments when the pathogen was absent. High-vigor soybean seed usually germinates well in prolonged cold conditions. In the standard cold germination test, in which soybean seed are subjected to 7 days of cold stress at $10^{\circ} \mathrm{C}$, seed lots with high vigor show high germination rates (AOSA 2009). Low-quality seed has greater seed exudation and, thus, stimulates soilborne pathogens to attack germinating seedlings (AOSA 2009; Hobbs and Obendorf 1972). The seed we used in this study was of high quality, with a $97 \%$ germination rate (data not shown); consequently, the effect of soilborne pathogens on emergence was not significantly confounded by characteristics of poor-quality seed.

Table 7. Sporangia germination of Pythium sylvaticum after exposure to soybean seed exudate or sterile water and incubation for $3 \mathrm{~h}$ at different temperatures

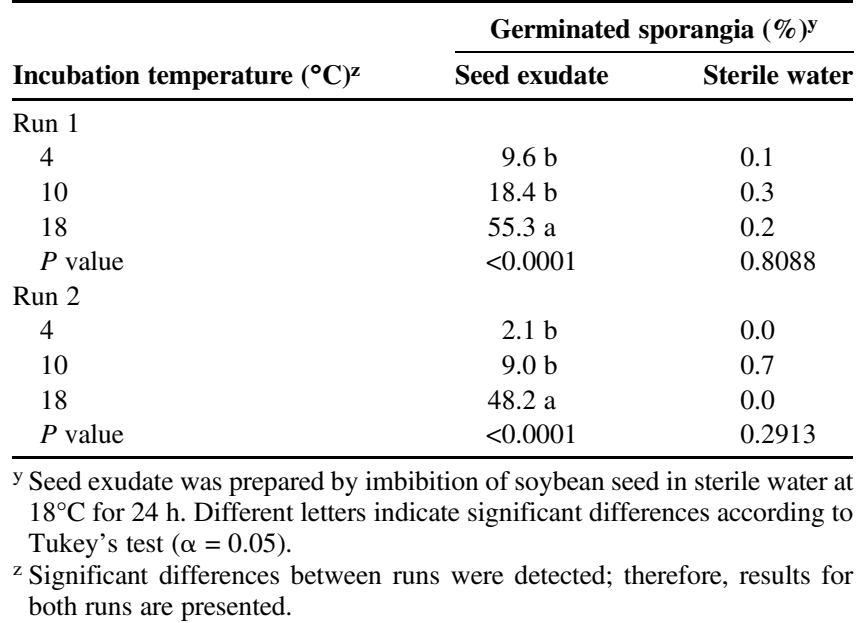


Cold stress under the conditions we used favored damping-off when the pathogen was present. We hypothesized that higher susceptibility to damping-off would occur in seed subjected to cold stress at planting because of the risk of chilling injury and greater solute leakage that would attract the pathogen. Unexpectedly, soybean was more susceptible to damping-off caused by $P$. sylvaticum when cold stress occurred 2 and 4 dap, which is well after imbibition, when chilling injury usually occurs. Still, soybean seedlings may be particularly susceptible to cold stress and other stresses initiated several days after imbibition. Wuebker et al. (2001) reported that soybean susceptibility to flooding damage was highest at 3 dap, and suggested that soybean seedlings may be more susceptible to stress at this developmental stage. Interestingly, isoflavone levels in the hypocotyl undergo a programmed decrease between 2 and 4 dap (Graham 1991). Isoflavonoids are phenylpropanoid-derived metabolites that have been involved in resistance to oomycetes such as $P$. aphanidermatum and Phytophthora sojae (Avanzato and Rupe 2011; Bhattacharyya and Ward 1986; Morris et al. 1991). A change in isoflavonoid levels was found in the hypocotyl and roots of 3-day-old soybean seedlings subjected to several days of cold stress at $1{ }^{\circ} \mathrm{C}$ and subsequently returned to $25^{\circ} \mathrm{C}$ for 3 days compared with seedlings that were not cold stressed (Posmyk et al. 2005). Further research is required to elucidate whether the increased susceptibility observed in our study when cold stress occurred at 2 to 4 dap is related to decreased levels of isoflavonoids, or other factors related to the structure of the root and other metabolic processes that may be impaired by cold stress at this specific stage.

In our study, we determined that soybean seedling growth is slower at $10^{\circ} \mathrm{C}$ and even more so at $4^{\circ} \mathrm{C}$. These results agree with Hatfield and Egli (1974), who reported that hypocotyl elongation was minimal at temperatures below $10^{\circ} \mathrm{C}$. Suboptimal temperatures for growth delay emergence and have been suggested to increase the chances for seedling infections caused by Pythium spp. (Martin and Loper 1999). However, the postchilling effect of cold stress on seedling growth has not been considered before in the occurrence of Pythium damping-off. In soybean seedlings subjected to $1^{\circ} \mathrm{C}$ for 2 days, Posmyk et al. (2005) observed postchilling stress in that seedling growth was slower over the following 3 days at $25^{\circ} \mathrm{C}$. Similarly, we observed reduced seedling growth during the rewarming period in plants previously subjected to cold stress at both 4 and $10^{\circ} \mathrm{C}$ in noninoculated plants and more so in inoculated plants. Thus, the rewarming period might present another important opportunity for seedling infection. It is possible that cold stress not only results in increased risk of seedling infection but also may favor colonization of the seedling by the pathogen because growth of the plant is initially slower even when more favorable conditions for seedling growth resume.

For this study, we selected Pythium sylvaticum as the pathogen causing damping-off of soybean. Although $P$. sylvaticum is the most frequently recovered species in the United States, there is a great diversity of Pythium spp. causing soybean seed and root rot (Rojas et al. 2017). Moreover, the aggressiveness of some pathogenic Pythium spp. can be enhanced or reduced at low temperatures (Matthiesen et al. 2016; Rojas et al. 2017; Thomson et al. 1971). Further research is required to determine whether the results observed in this study differ for other Pythium spp.

Although $P$. sylvaticum prefers warmer soil temperatures, we observed that the pathogen was still able to grow at 4 and $10^{\circ} \mathrm{C}$. Moreover, our data suggest that $P$. sylvaticum grows faster than soybean roots in the soil at these low temperatures. We also observed that seedling growth and emergence of soybean was delayed in the presence of the pathogen even at favorable temperatures $\left(18^{\circ} \mathrm{C}\right)$ for soybean growth. Although we did not do root rot assessments, we propose that some infection had occurred and, consequently, seedling growth was reduced.

Sugars, amino acids, and unsaturated fatty acids that are present in seed and root exudates stimulate sporangia germination (Nelson 1990; Ruttledge and Nelson 1997). We observed sporangia germination only when sporangia were flooded with soybean seed exudate solution. Moreover, temperature played a role in sporangia germination. The optimal temperature for sporangia germination in our study was $18^{\circ} \mathrm{C}$, which was the closest to the optimal temperature reported for mycelial growth $\left(25^{\circ} \mathrm{C}\right)$ (Van der Plaats-Niterink 1981).

In this study, we detected greater solute leakage when soybean seed were imbibed at $4^{\circ} \mathrm{C}$ in comparison with 10 and $18^{\circ} \mathrm{C}$. These data are similar to those reported by Bramlage et al. (1978), in which more solutes leaked from seed imbibed at $10^{\circ} \mathrm{C}$ and lower temperatures compared with seed imbibed at $20^{\circ} \mathrm{C}$. In our study, we also observed greater germination of $P$. sylvaticum sporangia in the presence of seed exudates from seed imbibed at $4^{\circ} \mathrm{C}$. Because sporangia germination is stimulated by seed exudates, it is possible that the quantity of the seed exudates varied at each temperature at which the seed was imbibed.

In our study, however, we measured exudation at $24 \mathrm{~h}$ after imbibition. Exudates are continually released from plant roots and their quantity and composition can vary over time depending on plant age, and can influence the composition and activity of microbial communities (Gransee and Wittenmayer 2000; Han et al. 2017). Moreover, cold stress may have affected exudation. Vančura (1967) analyzed exudates from maize and cucumber seedlings planted at $19^{\circ} \mathrm{C}$ and subjected to cold stress $\left(5^{\circ} \mathrm{C}\right) 48 \mathrm{~h}$ after planting, and found that cold stress increased the quantity of exudates and substantially increased exudation of amino acids. Fructose, saccharose, and three other oligosaccharides were detected only when maize seedlings were subjected to cold stress. In our study, we did not specifically quantify the amount of exudates or determine the composition of exudates. Consequently, we do not know if the increased germination of sporangia in exudates from seed imbibed at $4^{\circ} \mathrm{C}$ for $24 \mathrm{~h}$ was due to a higher concentration of some specific exudates or a different composition of exudates. Further research is needed to determine whether the quantity and composition of soybean seed exudates produced at 2 and 4 dap differs, if cold stress affects the composition of exudates, and the effect of the exudates on sporangia germination.

In this study, we found that cold stress increased soybean susceptibility to damping-off caused by $P$. sylvaticum, particularly when cold stress occurred 2 and 4 dap. P. sylvaticum delayed seedling growth and emergence at $18^{\circ} \mathrm{C}$. Also, P. sylvaticum reduced seedling growth in plants previously exposed to cold stress at 4 and $10^{\circ} \mathrm{C}$. Our data suggest that the increase in damping-off that we observed after a period of cold stress could be due to several factors, including the apparent growth rate advantage of the pathogen at low temperatures, reduced seedling growth after a period of cold stress, and increased solute leakage that stimulates germination of sporangia of $P$. sylvaticum. We also hypothesize that susceptibility to damping-off may be increased by physiological and metabolic changes that occur in the soybean seedling during germination and seedling development. Further research is required to elucidate why soybean seedlings are more susceptible to damping-off when cold stress occurs 2 and 4 dap.

\section{Acknowledgments}

We thank the Iowa State University Seed laboratory for help provided with solute leakage tests.

\section{Literature Cited}

Allen, T., Bradley, C., Sisson, A., Byamukama, E., Chilvers, M., Coker, C., Collins, A., Damicone, J., Dorrance, A., Dufault, N., Esker, P., Faske, T., Giesler, L., Grybauskas, A., Hershman, D., Hollier, C., Isakeit, T., Jardine, D., Kelly, H., Kemerait, R., Kleczewski, N., Koenning, S., Kurle, J., Malvick, D., Markell, S., Mehl, H., Mueller, D., Mulrooney, R., Nelson, B., Newman, M., Osborne, L., Overstreet, C., Padgett, G., Phipps, P., Price, P., Sikora, E., Smith, D., Spurlock, T., Tande, C., Tenuta, A., Wise, K., and Wrather, J. 2017. Soybean yield loss estimates due to diseases in the United States and Ontario, Canada, from 2010 to 2014. Plant Health Prog. 18:19-27.

AOSA. 2009. Seed Vigor Testing Handbook. Association of Official Seed Analysts (AOSA), Ithaca, NY.

Avanzato, M., and Rupe, J. 2011. Role of soybean seed exudates in cultivar resistance to Pythium aphanidermatum. (Abstr.) Phytopathology 101:S11.

Bhattacharyya, M., and Ward, E. 1986. Resistance, susceptibility and accumulation of glyceollins I-III in soybean organs inoculated with Phytophthora megasperma f. sp. glycinea. Physiol. Mol. Plant Pathol. 29:227-237

Bradley, C. A. 2008. Effect of fungicide seed treatments on stand establishment seedling disease, and yield of soybean in North Dakota. Plant Dis. 92:120-125. 
Bramlage, W. J., Leopold, A. C., and Parrish, D. J. 1978. Chilling stress to soybeans during imbibition. Plant Physiol. 61:525-529.

Cabane, M., Vincens, P., and Boudet, A. 1992. Protein synthesis at low temperatures in two soybean cultivars differing by their cold sensitivity. Physiol. Plant. 85: 573-580.

Campbell, C. L., and Madden, L. V. 1990. Introduction to Plant Disease Epidemiology. John Wiley \& Sons, New York.

Campbell, W., and Hendrix, F. 1967. A new heterothallic Pythium from southern United States. Mycologia 59:274-278.

De Bruin, J. L., and Pedersen, P. 2008. Soybean seed yield response to planting date and seeding rate in the Upper Midwest. Agron. J. 100:696-703.

Duke, S. H., Schrader, L. E., and Miller, M. G. 1977. Low temperature effects on soybean (Glycine max [L.] Merr. cv. Wells) mitochondrial respiration and several dehydrogenases during imbibition and germination. Plant Physiol. 60: 716-722.

Ellis, M., Broders, K., Paul, P., and Dorrance, A. 2011. Infection of soybean seed by Fusarium graminearum and effect of seed treatments on disease under controlled conditions. Plant Dis. 95:401-407.

Graham, T. L. 1991. Flavonoid and isoflavonoid distribution in developing soybean seedling tissues and in seed and root exudates. Plant Physiol. 95:594-603.

Gransee, A., and Wittenmayer, L. 2000. Qualitative and quantitative analysis of water-soluble root exudates in relation to plant species and development. J. Plant Nutr. Soil Sci. 163:381-385.

Han, L.-L., Wang, J.-T., Yang, S.-H., Chen, W.-F., Zhang, L.-M., and He, J.-Z. 2017. Temporal dynamics of fungal communities in soybean rhizosphere. J. Soils Sediments 17:491-498.

Hartman, G., Rupe, J., Sikora, E., Domier, L., Davis, J., and Steffey, K. 2015. Compendium of Soybean Diseases and Pests. American Phytopathological Society, St. Paul, MN.

Hatfield, J., and Egli, D. 1974. Effect of temperature on the rate of soybean hypocotyl elongation and field emergence. Crop Sci. 14:423-426.

Hobbs, P., and Obendorf, R. 1972. Interaction of initial seed moisture and imbibitional temperature on germination and productivity of soybean. Crop Sci. 12:664-667.

Ismail, R., Mullen, R., Stewart, C., and Knapp, A. 1989. Respiratory rates and alternative pathway capacity during early germination of soybean. Crop Sci. 29:976-980.

Keeling, B. 1974. Soybean seed rot and the relation of seed exudate to host susceptibility. Phytopathology 64:1445-1447.

Leopold, A. C. 1980. Temperature effects on soybean imbibition and leakage. Plant Physiol. 65:1096-1098.

Littlejohns, D., and Tanner, J. 1976. Preliminary studies on the cold tolerance of soybean seedlings. Can. J. Plant Sci. 56:371-375.

Martin, F. N., and Loper, J. E. 1999. Soilborne plant diseases caused by Pythium spp.: Ecology, epidemiology, and prospects for biological control. Crit. Rev. Plant Sci. 18:111-181.

Matthiesen, R., Ahmad, A., and Robertson, A. 2016. Temperature affects aggressiveness and fungicide sensitivity of four Pythium spp. that cause soybean and corn damping off in Iowa. Plant Dis. 100:583-591.

Morris, P., Savard, M., and Ward, E. 1991. Identification and accumulation of isoflavonoids and isoflavone glucosides in soybean leaves and hypocotyls in resistance responses to Phytophthora megasperma f. sp. glycinea. Physiol. Mol. Plant Pathol. 39:229-244.

Murillo-Williams, A., and Pedersen, P. 2008. Early incidence of soybean seedling pathogens in Iowa. Agron. J. 100:1481-1487.

Nelson, E. B. 1987. Rapid germination of sporangia of Pythium species in response to volatiles from germinating seeds. Phytopathology 77:1108-1112.

Nelson, E. B. 1990. Exudate molecules initiating fungal responses to seeds and roots. Plant Soil 129:61-73

Nelson, E. B. 2004. Microbial dynamics and interactions in the spermosphere. Annu. Rev. Phytopathol. 42:271-309.
Nelson, E. B., and Craft, C. M. 1989. Comparative germination of cultureproduced and plant-produced sporangia of Pythium ultimum in response to soluble seed exudates and exudate components. Phytopathology 79:1009-1013.

Parrish, D. J., and Leopold, A. C. 1977. Transient changes during soybean imbibition. Plant Physiol. 59:1111-1115.

Pedersen, P., and Elbert, B. 2004. Soybean growth and development. Iowa State University, University Extension, Ames, IA

Posmyk, M. M., Bailly, C., Szafrańska, K., Janas, K. M., and Corbineau, F. 2005. Antioxidant enzymes and isoflavonoids in chilled soybean (Glycine max (L.) Merr.) seedlings. J. Plant Physiol. 162:403-412.

Rizvi, S., and Yang, X. 1996. Fungi associated with soybean seedling disease in Iowa. Plant Dis. 80:57-60.

Robertson, A. E., and Munkvold, G. P. 2012. Seedling diseases reported in corn and soybean. Integr. Crop Manage. News 193. Iowa State University, Ames. https://lib.dr.iastate.edu/cropnews/193/

Rojas, J. A., Jacobs, J. L., Napieralski, S., Karaj, B., Bradley, C. A., Chase, T., Esker, P. D., Giesler, L. J., Jardine, D. J., Malvick, D. K., Markell, S. G., Nelson, B. D., Robertson, A. E., Rupe, J. C., Smith, D. L., Sweets, L. E., Tenuta, A. U., Wise, K. A., Chilvers, M. I. 2017. Oomycete species associated with soybean seedlings in North America-Part I: Identification and pathogenicity characterization. Phytopathology 107:280-292.

Ruttledge, T. R., and Nelson, E. B. 1997. Extracted fatty acids from Gossypium hirsutum stimulatory to the seed-rotting fungus, Pythium ultimum. Phytochemistry 46:77-82.

Serrano, M., and Robertson, A. 2016. Cold stress at planting increase susceptibility to damping-off caused by Pythium sylvaticum. (Abstr.). Phytopathology 106 S4.40.

Serrano, M., Wiggs, S. N., and Robertson, A. E. 2015. Evaluation of commercial seed treatments on soybean at three locations in Iowa in 2014. Integr. Crop Manage. Online publication. Iowa State University Extension and Outreach, Ames. https:// crops.extension.iastate.edu/cropnews/2015/02/evaluation-commercial-seedtreatments-soybean-three-locations-iowa-2014

Stanghellini, M., and Hancock, J. 1971a. Radial extent of the bean spermosphere and its relation to the behavior of Pythium ultimum. Phytopathology 61 : 165-168.

Stanghellini, M., and Hancock, J. 1971b. The sporangium of Pythium ultimum as a survival structure in soil. Phytopathology 61:157-164.

Thomson, T., Athow, K., and Laviolette, F. 1971. The effect of temperature on the pathogenicity of Pythium aphanidermatum, P. debaryanum, and P. ultimum on soybean. Phytopathology 61:933-935.

USDA-NASS. 2016. 2016 State Agriculture Overview (Iowa). Online publication. United States Department of Agriculture-National Agricultural Statistics Service. https://www.nass.usda.gov/Quick_Stats/Ag_Overview/stateOverview.php? state $=$ IOWA

Van der Plaats-Niterink, A. 1981. Monograph of the genus Pythium. Stud. Mycol. 21:1-244.

Vančura, V. 1967. Root exudates of plants. Plant Soil 27:319-328.

Vertucci, C. W., and Leopold, A. C. 1983. Dynamics of imbibition by soybean embryos. Plant Physiol. 72:190-193.

Weidenbenner, N. H., Rowntree, S. C., Wilson, E. W., Suhre, J. J., Conley, S. P., Casteel, S. N., Davis, V. M., Diers, B. W., Esker, P. D., and Specht, J. E. 2014 Fungicide management does not affect the rate of genetic gain in soybean. Agron. J. 106:2043-2054.

Wuebker, E. F., Mullen, R. E., and Koehler, K. 2001. Flooding and temperature effects on soybean germination. Crop Sci. 41:1857-1861.

Yang, X. 1997. Soybean Damping Off. Iowa State University, University Extension, Ames.

Yang, X. 1999. Pythium damping-off and root rot. Pages 42-44 in: Compendium of Soybean Diseases, 4th ed. G. L. Hartman, J. B. Sinclair, and J. C. Rupe, eds. American Phytopathological Society, St. Paul, MN. 